\title{
It's Not Just About the Game: A Study on Attitudes and Motivation of Malaysian Secondary Sports School Students in East Malaysia towards Learning English as a Second Language
}

\author{
Nursyaheedah Muhammad Isa ${ }^{1, *}$, Noor Azlinda Zainal Abidin ${ }^{1}$, Nabila Abdul Malek ${ }^{1}$, Mohamad Hazeem Mohmad Sidik ${ }^{2}$ \\ and Safirul Azli Abu Bakar ${ }^{3}$ \\ ${ }^{1}$ Centre for Modern Languages and Human Sciences, Universiti Malaysia Pahang, 26300 Gambang, Pahang, Malaysia \\ ${ }^{2}$ Faculty of Industrial Management, Universiti Malaysia Pahang, 26300 Gambang, Pahang, Malaysia \\ ${ }^{3}$ National Football Development Programme, National Sports Council of Malaysia, 57700 Kuala Lumpur, Malaysia
}

\begin{abstract}
In the past few years, Malaysian athletes have gained international recognition with their impressive, world-record breaking accomplishments. As a result of this, Malaysian athletes are finding themselves being interviewed and giving speeches at local and international events. For professional athletes, there is a need and a duty to be able to communicate their stories and experiences as well as giving real insight and opinions about their performances, confidently, to both local and global audiences. In addressing these audiences, it is important for these professional athletes to be confident and are able to converse well using the English language, especially so when addressing a global audience. However, some Malaysian athletes are facing difficulties in communicating confidently and coherently, especially in English. It is a recognised and acknowledged skill gap in which is believed should be tackled during the formative school years. It is possible that the skill gap stems from a lack of motivation and poor attitude beginning from secondary school. This paper discusses the findings of a study undertaken to investigate these issues further by carrying out a questionnaire survey on the attitudes and motivation of Malaysian secondary sports school students in East Malaysia towards learning English as a second language. The study reveals an overall positive attitude towards learning English by the sports students. In addition, the findings reveal that the sports school students are extrinsically and intrinsically motivated in learning English. The study concludes with recommendations for future research and is expected to make a contribution to the literature of attitudes and motivation especially for but not limited to secondary sports school students.
\end{abstract}

\section{Introduction}

Malaysian athletes are famous and looked up by other Malaysians due to their outstanding performances internationally and nationally. Due to their accomplishment, their popularity has made them public figures for some. Thus, they need to present themselves well not only in sports but also in other matters including the way they dress and even their communication skills especially in English. In order to master and be communicative competence in English, they should be equipped with skills related which help them in communicating. The need of communicating is not only meant for interacting when travelling abroad but it also helps them to present themselves better when being interviewed. As they are also known as the 'ambassador' of Malaysia, they have to represent the best for Malaysia not only in sports but also in communication.

However, due to limited practice and proper skills learnt, some athletes are not confident and ready to be interviewed by people especially in public. The lack of confidence and negative attitude towards language learning has made them poor in presenting themselves especially when being interviewed by the international journalists. Having low drive of motivation and negative perception towards language learning can impede the language learning process and results poor performance in communication. Therefore, this study investigates these issues on the attitudes and motivation of Malaysian secondary sports school students in East Malaysia towards learning English as a second language.

\section{Literature Review}

Learning or acquiring second language is often seen as difficult by most people especially students. In Malaysia, English language is learned and used as a second language but nevertheless the students are having difficulties in learning the language. English language is perceived as not important to the students' immediate needs thus decrease the motivation to learn the language (Oroujlou \& Vahedi, 2011). Attitude and motivation towards learning the second language has been the major

\footnotetext{
"Corresponding author: syaheedah@ump.edu.my
} 
concerns among researchers. According to Oroujlou \& Vahedi (2011), motivation varies among students and it is difficult to keep students motivation at a high level all the time. Thus, it is important to further explore and understand the literature on motivation and attitude.

\subsection{Motivation and Language Learning}

Motivation in present context of language learning is seen according to Gardner (1985) as "referring to the combination of effort plus desire to achieve the goal of learning the language plus favourable attitudes towards learning the language." The desire to learn the language combined with the effort put in the process and the satisfaction experienced at the end of the process is what motivation is all about. It helps the students to strive for the better. There are two types of motivation that is relevant to this study; intrinsic and extrinsic motivation.

Deci and Ryan (2008) identify intrinsic motivation as self-satisfaction feeling resulted from the ability to complete a task. Extrinsic motivation, on the other hand focuses on involving in an activity because of different reason or consequence. For example earning a reward or to avoid a punishment.

Dornyei and Csizer (1998) indicate that motivation is responsible for achievement in language learning, and without adequate motivation, learners with distinctive talents will not be able to fulfil such objectives, even if they have a good curriculum or teachers.

In Malaysian context, Samsiah et al.'s (2009) suggested that Malaysian students are generally extrinsically rather than intrinsically motivated. It is believed that students do not perceived the usefulness of learning English language for self-satisfaction but more of the reward they obtain when learn the language especially for future careers and development. Samsiah et al.'s findings also revealed that motivation either extrinsic or intrinsic do not directly influence students' English language performance.

\subsection{Attitudes and Language Learning}

As cited by Elyıldırım \& Ashton (2006), according to Brown (2000), attitudes are related to thoughts as well as to feelings and emotions. Attitudes govern how one approaches learning which in the case of language requires exposure to a different culture and also to the difficult task of mastering a second language.

Spolsky (2000) states that the attitudes towards the language hint at the learners' fears, feelings, or preconception about learning English as a second language. It is believed that students' decision to participate in language learning process are mostly depending on their experiences towards the process of learning and acquiring the language. The students' attitude are influenced by many factors. If the students experience success, the attitudes are reinforced, in contrast, if the students experience failure, the attitudes become more negative. This was supported by Samsiah et al. (2009), revealed that high achievers students have better attitude in learning English compared to the low achievers. In addition, female students have slightly better attitude in learning English compared to the male students. As such, attitudes may play an important role in language learning process as it is able to influence students' success or failure in their learning.

\section{Methodology}

\subsection{Research Design and Context}

This quantitative study employed a questionnaire survey to collect data. The procedure was carried out in a secondary sport's school in Gambang, Pahang. The school was established in 2012 and is the third Sport's School formed after Sekolah Sukan Bukit Jalil and Sekolah Sukan Tunku Mahkota Ismail. The school uses Bahasa Malaysia (BM) as medium of instruction.

\subsection{Sample Population}

47 male students participated in the survey irrespective of their English proficiencies. The sport's school accepted only male students into their football programme which resulted with the sample population being all male students. The population was made up of all Malay football students as there were only Malay students present during the data collection. 34 questionnaires were distributed and collected. In order to gauge their English proficiencies, the students' English Language result for the Ujian Penilaian Sekolah Rendah (UPSR) or also known as Primary School Achievement Test were used. Students were categorised into High Proficiency (HP) students, those who obtained Grade A for English, Average Proficiency (AP) students, those who obtained Grade B and Low Proficiency (LP) students, those who obtained Grades C, D and E.

\subsection{Research Tool}

A survey questionnaire adopted from Thang et al. (2011) was employed to investigate students' attitudes and motivation. The questionnaire adopted was originally translated into Bahasa Malaysia as translations into the mother tongue provides accuracy, clarity and flexibility for students in understanding the questionnaires (Ross, 2000). The survey questionnaire was previously adapted by Thang et al. (2011) from the Gardner's Attitude and Motivation Test Battery (AMTB) (Gardner, 1985). The questionnaire consists of 48 questions and has two sections. The first section consists of eight items. The first section was designed to elicit students' background information, the result of their USPR English paper, their perceptions of their own levels of motivation and their reading habits. The second section comprises of 40 items 
designed to extract information pertaining to the students' attitudes and motivation towards the learning of English. The Likert scale items were used to gauge students' responses and it ranged from 'strongly disagree' to 'strongly agree'. 20 items were aimed at eliciting information pertaining to students' attitudes while another 20 measured their motivation in learning English. For motivation, there were 10 items regarding intrinsic motivation and another 10 on extrinsic motivation.

\subsection{Research Procedures}

The questionnaire was distributed to the students during their English class after the students were briefed thoroughly on the purpose of the research. Students took about 15 minutes to complete the questionnaire. Scores were tabulated using SPSS Windows 23.0. The statistical measures used to analyse data were ranking of mean scores, one-way analysis of variance (ANOVA) and correlation coefficient. The purpose of ANOVA in this study was to compare the mean differences between attitudes and motivation of students of different English proficiency levels. The $\mathrm{p}$-value for significance was set at 0.05 . For differences in English proficiency levels, One Way ANOVA was used to determine significance since only one group of subjects was involved. In addition, the correlation coefficient was used to determine the correlation between the two variables; attitudes and motivation.

\section{Data Analysis}

The data were analysed using both descriptive and inferential tools. The descriptive tools employed were ranking and correlation coefficient and ANOVA was the inferential tool utilised.

\subsection{Students' Background Information}

The questionnaires were distributed to one class of form one students, $4(11.8 \%)$ students were HP students. 8 (23.5\%) were AP students and the remaining 22 (64.7\%) were LP students.

\subsection{Attitudes and Motivation towards Learning English: Ranking of Positive Attitudes}

Table 1 shows the mean score ranking of 10 items for positive attitudes.

Table 1. Rank of mean score for positive attitudes

\begin{tabular}{cccc}
\hline \multicolumn{1}{c}{ Items } & Mean & $\begin{array}{r}\text { Std. } \\
\text { Deviation }\end{array}$ \\
\hline 1 & $\begin{array}{c}\text { English is an important part of the school } \\
\text { programme }\end{array}$ & 3.35 & .646 \\
2 & Learning English is very great & 3.24 & .496 \\
3 & I have desire to learn good English & 3.24 & .654 \\
4 & I find learning English is very interesting & 3.21 & .538 \\
5 & I plan to learn as much English as possible & 3.03 & .627 \\
6 & I put a lot of effort in learning English & 3.03 & .627
\end{tabular}

$\begin{array}{llll}7 & \text { I enjoy my English classes } & 3.00 & .603\end{array}$

$\begin{array}{llll}8 & \text { I really enjoy learning English } & 2.97 \quad & .577\end{array}$

9 When I have English exercises, I will finish
it immediately $\begin{array}{lll}10 & \text { I would read English newspapers and } \\ \text { magazines as often as I could }\end{array} \quad 2.74 \quad .666$ Average mean 3.066

\section{Key:}

Item 1 - Awareness of the importance of English Item 3, 5, 6- Expression of desire to improve English Item 2, 4, 8 - Expression of interest in learning English Item 7, 9, 10 - Actual effort towards learning and improving English

Item 1 which gauges the students on their awareness of the importance of English ranks the highest. This goes to show that students are very much aware of the importance of English either in their education, in their daily lives and for their futures. Subsequent items 2, 3, 4, $5,6 \& 8$ depict interest in learning English and expression of desire to learn English. Since these items generally rank higher than 2.5 , it shows that there is a tendency towards this direction and when translated into action it shows that the students actually put in the effort to as indicated by the high mean for items $7,9 \& 10$ that show actual interest and effort in learning and improving English in and out of the classroom. The students, despite majority being of low English proficiency, are still very much interested in learning English and improving their English proficiencies. Regardless, teachers will still need to make continuous effort to keep making their English classes more interesting and interactive.

\subsection{Attitudes and Motivation towards Learning English: Ranking of Negative Attitudes}

Table 2 displays the mean score ranking of 10 items for negative attitudes.

Table 2. Rank of mean score for negative attitudes

\begin{tabular}{|c|c|c|c|}
\hline Rank & Items & Mean & $\begin{array}{r}\text { Std. } \\
\text { Deviation }\end{array}$ \\
\hline 1 & It is hard to learn English & 2.62 & .853 \\
\hline 2 & $\begin{array}{l}\text { I prefer to read material in other languages } \\
\text { rather than English }\end{array}$ & 2.56 & .660 \\
\hline 3 & I find doing English exercises difficult & 2.44 & .660 \\
\hline 4 & $\begin{array}{l}\text { I force myself to listen to the teacher during } \\
\text { English classes }\end{array}$ & 2.41 & .925 \\
\hline 5 & I feel stress in learning English & 2.26 & .567 \\
\hline 6 & $\begin{array}{l}\text { I never think of improving my English } \\
\text { languages }\end{array}$ & 2.03 & .717 \\
\hline 7 & $\begin{array}{l}\text { During English classes, I become completely } \\
\text { boring }\end{array}$ & 1.88 & .478 \\
\hline 8 & $\begin{array}{l}\text { When I leave school, I shall give up the } \\
\text { study of English entirely because I am not } \\
\text { interested in it }\end{array}$ & 1.82 & .576 \\
\hline 9 & I think that learning English is dull & 1.68 & .589 \\
\hline 10 & Learning English is a waste of time & 1.50 & .615 \\
\hline \multicolumn{2}{|r|}{ Average mean } & 2.361 & \\
\hline
\end{tabular}


Key:

Item 1, 2, 3, 5 - Expression of difficulty in learning English

Item 4, 7, 9 - Perception of English as being

uninteresting

Item $6,8,10$ - Indication of no interest in learning or improving English

The mean scores for negative attitudes towards English are lower than positive attitudes. All of the mean scores are below the level of 3 (i.e. the agree level) which is a positive sign. The first four items that rank highest (with mean scores above or approaching 2.50) are items relating to the difficulty involved in learning English. It can be observed that the students have problems learning English and prefer learning another language. Items $7 \&$ 9 investigate whether students find learning English uninteresting and the low mean scores (of below 2.30) suggests that they do not really find learning English boring with the exception of item 4 . Item 4 has a mean score of 2.41 (approaching mean score of 2.50) which shows that the students find English to be uninteresting that they have to force themselves to listen to their English teachers. Finally, the low mean scores for items $6,8 \& 10$ show that the students do not think that learning English is a waste of time and are still interested in improving their English when they leave school.

\subsection{Motivation towards Learning English: Ranking of Intrinsic Motivation}

Table 3 displays the mean score ranking of 10 items for intrinsic motivation.

Table 3. Mean scores ranking of intrinsic motivation towards learning English

\begin{tabular}{|c|c|c|c|}
\hline Rank & Items & Mean & $\begin{array}{r}\text { Std. } \\
\text { Deviation }\end{array}$ \\
\hline 1 & $\begin{array}{l}\text { Learning English will allow me to converse } \\
\text { with more varied people }\end{array}$ & 3.62 & .652 \\
\hline 2 & Learning English is good for self-development & 3.56 & .561 \\
\hline 3 & $\begin{array}{l}\text { Learning English will enable me to better } \\
\text { understand and appreciate English literature }\end{array}$ & 3.41 & .500 \\
\hline 4 & $\begin{array}{l}\text { I learn English in order to improve my English } \\
\text { language skills }\end{array}$ & 3.38 & .604 \\
\hline 5 & $\begin{array}{l}\text { Learning English allows me to participate } \\
\text { more freely in the activities of other cultural } \\
\text { groups }\end{array}$ & 3.35 & .597 \\
\hline 6 & $\begin{array}{l}\text { Learning English will allow me to be more at } \\
\text { ease with English speakers }\end{array}$ & 3.35 & .597 \\
\hline 7 & I feel more confident in learning English & 3.29 & 629 \\
\hline 8 & I make better use of my time to learn English & 3.26 & .666 \\
\hline 9 & I study English because I enjoy learning it & 3.21 & .687 \\
\hline 10 & $\begin{array}{l}\text { I learn English because it is something that I } \\
\text { always want to do }\end{array}$ & 3.00 & .550 \\
\hline Avera & ge mean & & \\
\hline
\end{tabular}

Key:

Item 2, 4 - Learning English to improve

Item 1, 3, 5, 6 - Learning English for social reasons Item 9, 10 - Learning English to satisfy interest and enjoyment

Items 2 and 4 have mean scores of above 3.00 which depicts that students have interest to improve themselves for self-development, and to develop their language skills. The mean scores of above 3.00 for items $1,3,5,6$ further reveal that students seem to be willing to learn English for social purposes and also to understand the literature and cultures of other people. Similar for items $9 \& 10$, with the mean score of 3.21 and 3.00 respectively, suggests that students are willing to learn English for interest and enjoyment. With a mean score of 3.29 and 3.26 respectively, students are also confident in learning English (Item 7) and actually make better use of their time to learn the language (Item 8). Considering that all items display a mean score of more than 3.00 it shows that students possess positive intrinsic motivation towards learning English.

\subsection{Motivation towards Learning English: Ranking of Extrinsic Motivation}

Table 4 shows the mean score ranking of 10 items for extrinsic motivation.

Table 4. Mean score ranking of extrinsic motivation towards learning English

\begin{tabular}{|c|c|c|c|}
\hline$\underline{\text { Rank }}$ & Item & Mean & $\begin{array}{l}\text { Std. } \\
\text { Deviati } \\
\text { on }\end{array}$ \\
\hline 1 & $\begin{array}{l}\text { Learning English is important for my future } \\
\text { career }\end{array}$ & 3.65 & .544 \\
\hline 2 & $\begin{array}{l}\text { I study English because I want to do well in } \\
\text { my examination }\end{array}$ & 3.62 & .551 \\
\hline 3 & $\begin{array}{l}\text { Learning English is useful in getting a good } \\
\text { job }\end{array}$ & 3.62 & .604 \\
\hline 4 & $\begin{array}{l}\text { I learn English because it makes me a more } \\
\text { knowledgeable person }\end{array}$ & 3.56 & .561 \\
\hline 5 & $\begin{array}{l}\text { I learn English because I need it to further my } \\
\text { studies overseas }\end{array}$ & 3.41 & .701 \\
\hline 6 & $\begin{array}{l}\text { Learning English is important for me because } \\
\text { other people will respect me more if I am } \\
\text { good in English }\end{array}$ & 3.29 & .629 \\
\hline 7 & I study English in order to please my family & 3.15 & .821 \\
\hline 8 & $\begin{array}{l}\text { I learn English because I can contribute more } \\
\text { to the society }\end{array}$ & 3.15 & .500 \\
\hline 9 & $\begin{array}{l}\text { I need to learn English in order to finish high } \\
\text { school }\end{array}$ & 2.79 & .946 \\
\hline 10 & $\begin{array}{l}\text { I feel that no one is really educated unless he } \\
\text { is fluent in English language }\end{array}$ & 2.74 & .751 \\
\hline & Average mean & 3.298 & \\
\hline
\end{tabular}

Key:

Item 1, 3 - Learning English for future career

Item 2, 4, 5, 9 - Learning English for education

Item 6, 7, 8, 10 - Learning English due to external influences

The mean score of above 3.00 for items $1,2,3,4, \& 5$ suggest that students have a strong desire to learn English for future career and for the purpose of education. However, there is an exception for item 9 whereby the mean score is 2.79 (below mean score of 3.00). This findings suggest that students slightly agree that they need to learn English to complete their high school. For items $6,7 \& 8$ with a mean score of 3.29 , 3.15 and 3.15 respectively shows that students are influenced by external factors such as earning the respect of other people, pleasing family and contributing to society, for wanting to learn English. However, for item 10 with a mean score of 2.74 , contrary to popular beliefs, 
some students does not feel that intelligence is measured by one's fluency or proficiency in the English language.

\subsection{Reliability Analysis}

According to Thang et al. (2011), prior to comparing the group mean scores it is necessary to determine whether the grouping of items is reliable. For that purpose, the alpha reliability test was performed. The Cronbach Alpha reliability value for positive attitudes is 0.701 , for negative attitudes is 0.709 , for intrinsic motivation is 0.756 , and for extrinsic motivation is 0.649 . The Cronbach Alpha reliability values for positive attitude, negative attitude and intrinsic motivation are all above 0.700 , which indicate that the grouping of the three groups of items is reliable. However, the The Cronbach Alpha reliability value for extrinsic motivation is 0.649 (less than 0.700). Nevertheless, according to Hair et al. (2014), the values between $0.690-0.600$ is considered to be acceptable.

\subsection{Overall Attitudes towards Learning English}

The results of the students' attitudes towards the learning of English were divided into sub-categories. The mean scores of positive and negative attitudes were divided into two sub-categories. Mean scores of 1.00-2.49 was classified as disagree and mean scores of 2.50-4.00 was classified as agree.

Table 5. Students' overall attitudes towards the learning

\begin{tabular}{|c|c|c|c|c|c|}
\hline \multicolumn{6}{|c|}{ of English } \\
\hline $\begin{array}{c}\text { Subcategories } \\
\text { for positive } \\
\text { attitudes }\end{array}$ & $\mathrm{n}$ & $\%$ & $\begin{array}{c}\text { Subcategories } \\
\text { for negative } \\
\text { attitudes }\end{array}$ & $\mathrm{n}$ & $\%$ \\
\hline $\begin{array}{c}\text { Disagree } \\
\text { (mean 1.00- } \\
2.49)\end{array}$ & 2 & $5.8 \%$ & $\begin{array}{c}\text { Disagree } \\
\text { (mean 1.00- } \\
2.49)\end{array}$ & 29 & $\begin{array}{c}85.3 \\
\%\end{array}$ \\
\hline $\begin{array}{c}\text { Agree } \\
\text { (mean 2.50- } \\
4.00)\end{array}$ & 32 & $94.2 \%$ & $\begin{array}{c}\text { Agree } \\
\text { (mean 2.50- } \\
4.00)\end{array}$ & 5 & $\begin{array}{c}14.7 \\
\%\end{array}$ \\
\hline & 34 & 100.0 & & 34 & 100.0 \\
\hline
\end{tabular}

As shown in Table 5, 94.2\% of the students agreed that they have positive attitudes in learning English and only $5.8 \%$ disagreed. The data portrays that students possess promising attitudes towards learning English. In addition, $85.3 \%$ of the students disagreed that they have negative attitudes and only $14.7 \%$ admitted that they have negative attitudes towards the learning of English, which is further supported the fact that the students in general, have encouraging, favourable and promising attitudes towards the learning of the English language.

\subsection{Relationship between Attitudes and Motivation}

To investigate the relationship between attitudes and motivation in learning English, Pearson correlation was carried out. The result is presented in Table 6 .

Table 6 . The result of correlation analysis performed on attitudes and motivation

\begin{tabular}{lllll}
\hline & $\begin{array}{l}\text { Positive } \\
\text { attitude }\end{array}$ & $\begin{array}{l}\text { Negative } \\
\text { attitudes }\end{array}$ & $\begin{array}{l}\text { Intrinsic } \\
\text { Motivation }\end{array}$ & $\begin{array}{l}\text { Extrinsic } \\
\text { motivation }\end{array}$ \\
\hline $\begin{array}{l}\text { Positive } \\
\text { attitude }\end{array}$ & 1 & & & \\
$\begin{array}{l}\text { Negative } \\
\text { attitudes }\end{array}$ & -0.065 & 1 & 1 & \\
$\begin{array}{l}\text { Intrinsic } \\
\text { Motivation }\end{array}$ & $0.699 * *$ & -0.055 & 1 & \\
$\begin{array}{l}\text { Extrinsic } \\
\text { motivation }\end{array}$ & 0.147 & 0.122 & $0.395^{*}$ & 1 \\
\hline
\end{tabular}

**Correlation is significant at the 0.01 level (2-tailed)

* Correlation is significant at the 0.05 level (2-tailed)

As can be seen from Table 6, positive attitudes are positively correlated with intrinsic motivation $(\mathrm{r}=$ 0.699 ) at 0.01 significant level. Intrinsic motivation is significantly correlated to extrinsic motivation $(r=0.395)$ at 0.05 significant level. On the other hand, extrinsic motivation is not correlated to positive or negative attitudes. The findings illustrates that students who are intrinsically motivated have more positive attitudes as opposed to negative attitude in learning English, as compared to extrinsically motivated students. Additionally, these intrinsically motivated students according to Thang et al. (2011), are also more likely to be extrinsically motivated as well. Thus, the findings suggests that students whom are intrinsically motivated have a high probability to be a more successful English learners as having positive attitudes can and will drive them to success in learning English.

\subsection{Comparing the Attitudes and Motivation of Students of Different Proficiency}

Table 7 displays the differences in mean score of learning attitudes and motivation among students of different proficiency levels.

Table 7. The results of one way ANOVA performed on

learning attitudes and motivation among proficiency

\begin{tabular}{|c|c|c|c|c|c|c|}
\hline & $\begin{array}{c}\text { Proficiency } \\
\text { level of } \\
\text { student }\end{array}$ & Mean & $\begin{array}{l}\text { Std. } \\
\text { dev }\end{array}$ & df & $\mathrm{F}$ & $\begin{array}{c}\text { Sig } \\
(\mathrm{P}- \\
\text { value) }\end{array}$ \\
\hline \multirow{3}{*}{$\begin{array}{l}\text { Positive } \\
\text { attitudes }\end{array}$} & HP & 3.150 & 0.1291 & \multirow{3}{*}{2} & \multirow{3}{*}{0.237} & \multirow{3}{*}{0.790} \\
\hline & AP & 3.0125 & 0.1807 & & & \\
\hline & LP & 3.0682 & 0.3822 & & & \\
\hline \multirow{3}{*}{$\begin{array}{l}\text { Negative } \\
\text { attitudes }\end{array}$} & HP & 2.1250 & 0.2630 & \multirow{3}{*}{2} & \multirow{3}{*}{0.074} & \multirow{3}{*}{0.929} \\
\hline & $\mathrm{AP}$ & 2.1625 & 0.3068 & & & \\
\hline & LP & 2.104 & 0.3958 & & & \\
\hline \multirow{3}{*}{$\begin{array}{l}\text { Extrinsic } \\
\text { motivation }\end{array}$} & HP & 3.600 & 0.3652 & \multirow{3}{*}{2} & \multirow{3}{*}{1.338} & \multirow{3}{*}{0.277} \\
\hline & $\mathrm{AP}$ & 3.288 & 0.2696 & & & \\
\hline & LP & 3.318 & 0.3514 & & & \\
\hline \multirow{3}{*}{$\begin{array}{c}\text { Intrinsic } \\
\text { motivation }\end{array}$} & HP & 3.3250 & 0.320 & \multirow{3}{*}{2} & \multirow{3}{*}{0.031} & \multirow{3}{*}{0.970} \\
\hline & AP & 3.2750 & 0.3105 & & & \\
\hline & LP & 3.30 & 0.3532 & & & \\
\hline
\end{tabular}

*The mean difference is significant at the 0.05 level

The results of one way ANOVA showed that in positive attitudes variables there are no significant difference between all of the proficiency levels of student as the p- 
value is not significant at 0.790 . But, it can be seen that the means score for all of the Proficiency levels of student exceed 3.0 where they had positive attitude in learning English. In contrary, the ANOVA result in negative attitudes showed that students are in disagreement with negative attitudes regardless of any of the proficiency levels. In addition, result also indicated that there is no significant different between all of the proficiency levels of student as the p-value is not significant at 0.929 . This indicated that students do have neither negative perception nor negative expression towards learning English.

Next, in the extrinsic motivation variable it showed that HP students have high mean value with 3.600 and AP students have the lowest mean value by on 3.288. But, in the ANOVA analysis it was found that there is no significant difference between all of the proficiency levels towards extrinsic motivation. Other than that, Students are also unanimously agree with intrinsic motivation towards learning English regardless of any proficiency levels. With the significant value of 0.970 , it depicts that there is no significant different between the students for each of the proficiency levels towards intrinsic motivation.

\section{Discussion and Conclusion}

From the study, Malaysian secondary sports school students have shown positive attitude towards learning English language. Positive language attitudes let learners have positive bearings towards learning English and this is especially important as it will significantly contribute to the success of second language learning (Samsiah et al.,2009; Mohamad Jafre, 2012).

Positive relationship between higher proficiency level and positive attitudes and motivation to learn English among the students of Sport School are also seen in the result of the study. These findings correlate with the findings of Samsiah et al (2009) that Malaysian students are generally more extrinsically as opposed to intrinsically motivated in learning English and the similar results can be seen from studies carried out in other parts of the world (Gayton, 2010). Attitudes and motivation goes hand in hand as both elements need to coexist to achieve a successful language learning experience (Gardner, 1985). Students with positive attitudes and high level of motivation are generally more successful than those with negative attitudes and low motivation (Samsiah et al., 2009).

The findings also show that students' extrinsic (average mean $=3.343$ ) and intrinsic (average mean $=3.298$ ) motivation in learning English complement one another. Both of the motivation are fairly seen contributing to students' motivation. The intrinsic motivation which comes from learning to improve oneself and learning for social reasons will help to motivate students in learning English Language. Meanwhile, the external motivation they have is due to the external rewards which they get if they are able to be proficient in English. The students feel the importance of the English language as it benefits them for future career and education.

From the results given, the skill gap which found missing during the study in secondary school can be accomodated with proper trainings on English communication as part of their preparation to represent Malaysia in sports. These communication trainings should be incorporated just to keep them motivated in learning English, gain confidence and be competence in the language. The ability to communicate in English might be seen as small part to some, but as a whole it helps to make them confident in presenting themselves in public especially when interviewed. With input given in trainings and sufficient time of communication practices, it is hoped that they will make them better communicators. It is strongly recommended that contribution to the literature of attitudes and motivation especially for but not limited to secondary sports school students should be explored further.

\section{References}

Brown, H. D. (2000) Principles of language learning and teaching. 4th ed. White Plains, NY: Addison Wesley Longman.

Cook, V. (1991). Second language learning and language teaching. London: Edward Arnold.

Deci, E. L., \& Ryan, R. M. (2008). Facilitating optimal motivation and psychological well-being across life's domains. Canadian Psychology, 49, 14-23. doi: 10.1037/0708-5591.49.1.14

Dornyei, Z. \& Csizer, K. (1998). Ten Commandments for motivating language learners: results of an empirical study. 2(3). 205-229.

Elyıldırım, S. \& Ashton, S. (2006). Creating Positive Attitudes towards English as a Foreign Language. 44(4). 2-21.

Gardner, R. C. (1985) .Social psychology and second language learning: The role of attitudes and motivation. London: Edward Arnold.

Gayton, A. (2010). Socioeconomic Status and Language - Learning Motivation: To What Extent does the Former Influence the Latter? Scottish Languages Review. 22, 17-28.

Hair, J., Hult, G. T. M., Ringle, C., and Sarstedt, M. (2014). A Primer on Partial Least Squares Structural Equation Modeling (PLS-SEM). Los Angeles: SAGE Publications, Incorporated.

Karahan, F. (2007). Language attitudes of Turkish students towards the English language and its use in Turkish context. Journal of Arts and Sciences, 7, 73-87. 
Mohamad Jafre Zainol Abidin. (2012). EFL Students Attitudes Towards Learning English Language: The Case of Libyan Secondary School Students. Asian Social Science, 8: 119-134

Oroujlou, N., \& Vahedi, M. (2011). Motivation, attitude, and language learning. Procedia - Social and Behavioral Sciences, 29, 994-1000. doi: 10.1016/j.sbspro.2011.11.333

Ross, N. J. (2000). Interference and Intervention: Using Translation in the EFL Classroom.

Modern English Teacher, 9 (3), 61-66.

Samsiah Bidin, Kamaruzaman Jusoff, Nurazila Abdul Aziz, Musdiana Mohammad Salleh \& Taniza Tajudin. (2009). Motivation and attitude in learning English among UiTM students in the northern region of Malaysia. English Language Teaching. Vol. 2(2), 16-20.

Spolsky, B. (2000). Language motivation revisited: Anniversary article. Applied Linguistics, 20 (2), 157 169. http://dx.doi.org/10.1093/applin/21.2.157

Thang, S. M., Ting, S. L., \& Jaafar, N. M. (2011). Attitudes and motivation of Malaysian secondary students towards learning English as a second language: A case study. 3L; Language, Linguistics and Literature, The Southeast Asian Journal of English Language Studies, 17(1), 40-54. 